\title{
The role of civil society organisations in climate change governance: lessons from Quintana Roo, Mexico
}

\section{Susan Baker, Bárbara Ayala-Orozco and Eduardo García-Frapolli}

Abstract: To examine the role of civil society organisations (CSOs), including non-governmental environmental organisations, in climate governance, a case study approach in the coastal zone of Quintana Roo, Mexico is utilised. Focus groups with key stakeholders, in-depth faceto-face, and online interviews were employed to examine key actor perceptions of climate change risk and their involvement in climate governance, across scale. Participation by CSOs is shaped by a variety of factors, including constitutional arrangements, regulatory regimes, administrative traditions and structures, and a wider set of beliefs about moral responsibility and the exercise of civic duty. CSO participation across multilevel governance scales provides an array of inputs to help address climate vulnerabilities in the coastal zone of Quintana Roo. Especially under conditions of weak administrative capacity and corrupt government, certain enabling institutional conditions are needed. This creates complex contexts in which CSOs emerge, networks develop, alliances are formed, and barriers to effective participation endure.

Keywords: Non-governmental organisations, environmental NGOs, multilevel governance, participation, climate vulnerabilities, coastal zones.

Notes on the authors: see end of the article.

(C) The author(s) 2021. This is an open access article licensed under a

Creative Commons Attribution-NonCommercial-NoDerivs 4.0 Unported License 


\section{Introduction}

A consensus has emerged, in both climate governance regimes and in the scientific literature, that climate change adaptation should involve multiple actors from the public and private sectors and from across civil society (IPCC 2014). This view forms part of a shift from seeing public policy as a modernist, technical, and state-directed activity (Peters \& Pierre 1998) to understanding public policy as taking place through complex networks and negotiations, downwards through multilevel governance scales, from the federal, State, and local levels, and outwards to civil society and economic actors. This shift in the making of public policy is expected to result in locally appropriate actions and thus increase policy effectiveness (Rootes et al. 2012). This broader participation by non-state actors also has the potential to enhance the democratic legitimacy of environmental governance (Bäckstrand 2006a).

There is growing recognition that both public and private actors are embedded in existing webs of rules, resources, and hierarchies, which shape their actions and policy outcomes (Kooiman 2003). How roles and responsibilities are shared across the public and private spheres, and through the multiple levels of governance, depends not only on administrative traditions (Peters \& Pierre 1998), legal regulations, and existing administrative structures, but also on the wider collection of normative settings built on shared assumptions and a deeper level of taken-for-granted beliefs and codes of conduct, structures, and actor relations (Klein \& Juhola 2018). Operating within these embedded contexts, power relations, and institutional structures can undermine both the democratic nature of policymaking and the effectiveness of policy by reproducing path-dependent governance processes with business-as-usual outcomes (Newig \& Fritsch 2009). Furthermore, changes in governance patterns, which see private organisations play both formal and informal public policy roles, raises the issue of how the public interest is pursued in these circumstances.

There is increased recognition that the governance of climate change is taking a hybrid form, one that combines public and private authority in governance (Baker et al. 2020). While the substantive participation of private actors in climate governance has been researched (Bäckstrand 2006b), whether 'hybrid' forms enhance governmentality - that is, the practices through which matters are governed so to improve environmental outcomes - remains limited. Yet, as Purcell reminds us, the political field - as reflected in governance arrangements - is now irreducibly plural (Purcell 2009).

In addition, forms of multi-actor governance are also created through a multitude of civil society coalitions, alliances, and networks, engagements that are often as much about locally focused actions, as they are about directly shaping formal policy (Newell 
et al. 2012). However, the focus of the literature has been on institutionalised hybrid authority, through co-management, public-private partnerships, and social-private partnerships (Lemos \& Agrawal 2006). In this article, we widen the focus to examine hybrid forms of governance in which a complex array of state-led, regulatory governance operates with self-organised interests to engage in forms of steering that are not necessarily formalised. Furthermore, there is an underlying assumption in the literature that the arena in which the dynamics of hybrid governance plays out lies within the liberal democratic order, within Western, welfare states. Distancing ourselves from the Weberian, state-centric narratives, grounded in the European experiences of state formation (Baker et al. 2020), enables the article to examine the experience of hybrid governance in other state contexts. The case of Quintana Roo provides an opportunity to examine governance in the context of a weak state presence, where the system of public administration is only emerging as municipality formation takes place, and in the context of state corruption and lack of transparency.

This article examines the role of civil society organisations (CSOs) in climate governance, focusing on the case of Quintana Roo, Mexico. Mexico has been identified as particularly vulnerable to the impacts of climate change, with the coastal region of the Caribbean Sea, where Quintana Roo is located, seen as most vulnerable to its combined impacts (Rubin \& Rossing 2012). These impacts include an increase in the sea surface temperature, a situation that favours the occurrence of more frequent and intense hurricanes (IPCC 2007). Natural ecosystems may be endangered by a changing climate, including the ecologically important Mesoamerican Reef (UNDP 2020). This problem is exacerbated by urbanisation, irregular settlement growth, and heavy deforestation. The State of Quintana Roo is one of the fastest growing sub-regions and the largest tourist destination in Latin America. The continuous expansion of the tourism sector along the coastline and the associated rapid population growth has brought a marked degradation of coastal ecosystems (Pedrozo-Acuña et al. 2015). The tourism industry is very sensitive to sea level rises, yet the coral reefs protecting the Mexican Caribbean coastline have degraded because of tourism-related land use changes (Nature Conservancy 2018). The construction of hotels on fragile coastal lands has resulted in increased sediment run-off, to which coral reefs are particularly sensitive, and there has also been extensive deforestation, and loss of mangroves despite their having legal protection under Mexican law. Some of this destruction is illicit and clandestine (Murray 2007). Another major problem affecting the coastal region is untreated sewage outflow into the marine ecosystem, and high levels of water consumption from tourism and population growth. In addition, changes in temperature and precipitation add further pressure to an agricultural system that is experiencing intense drought, but which lacks infrastructure and financial support. Water availability may also be reduced by climate change, and in Quintana Roo water and sewage 
service demands cannot currently be met by existing infrastructure and natural water availability. Thus, water is transferred from distant watersheds and untreated sewage is disposed of into the sea. In this context, the rapid population and urban growth occurring in the State, particularly in the coastal zone, further increase vulnerability to climate change (Sosa-Rodriguez 2014). The capacity of the system of public administration in the State to address these climate risks and vulnerabilities is weak, including in terms of financial resources and expertise, and in relation to governance, including policy implementation, where efforts to address climate change have the potential to be seen as disruptive to the current economic development and growth trajectory (Baker et al. 2020).

It is within this context that the State of Quintana Roo sees a highly developed and dense network of CSOs operate. This article examines the role of CSOs in climate governance in the State. It begins by examining the literature on the role of CSOs in climate governance, then details the methods used. This is followed by a general discussion on climate vulnerabilities in Mexico and more specifically in the case of Quintana Roo, and how these are being addressed in public policy. Having turned to the case of Quintana Roo, the administrative context is detailed, and findings on the role of CSOs in climate change governance are presented, thematically grouped. The Conclusion draws together the threads of analysis to indicate the significance of the findings for our understanding of the role of CSOs in climate governance. The article puts forward an analysis that combines consideration of institutional setting, on the one hand, and, on the other, the actor-related processes that operate to shape climate governance.

\section{Civil society organisations and climate change governance}

CSOs are voluntary associations that explicitly seek to shape the rules that govern different aspects of social life and that are institutionally separate from state actors (Bernauer \& Gampfer 2013: 1). Non-governmental organisations (NGOs), and nonprofit business-related organisations, such as chambers of commerce or trade associations, are also organisational forms of civil society (Vormedal 2008). Here, we focus on CSO participation, which refers to input from the public into the process of governance of matters that relate to the public sphere (Brooker et al. 2019). Indeed, so pervasive has been the shift to participatory practices that governments are increasingly relying on a network of decision-making relationships that link government and civil society across many scales. This new form of governance is in widespread use in natural resource management, including forest and watershed management, conservation, and planning (Lane \& Morrison 2006). 
Arguments about the importance of civil society participation can be grouped into two broad categories. First, there are instrumental claims, which hold that CSO participation in public governance provides knowledge to enhance problem-solving capacity, which in turn leads to more effective and efficient policy implementation (Baker \& Chapin 2018). This role is of particular importance in countries with weak capacity in their systems of public administration. Here the role of CSOs in problem identification, scientific data collection, and policy research can come to the fore. This also facilitates the inclusion of local or tacit knowledge in public policymaking.

A second group of arguments are normative in appeal, based on claims that participation supports democratic values by fostering a more inclusive and deliberative form of public policy decision-making. This in turn can enhance public support for policy and reduce policy conflict. For instance, non-state actors can give voice to under-represented groups, thereby legitimising and validating policy decisions and improving the democratic quality of a polity (Bäckstrand \& Kuyper 2017). These normative dimensions are frequently a component of broader discussions on developing community and deepening democracy (Baker \& Chapin 2018). Nevertheless, some have questioned the strength of CSO grassroots linkages, especially those that have strong ties to international doners (Banks et al. 2015).

Engagement can also promote governance transparency, thus mitigating the risk of governments catering primarily to influential domestic interest groups (Dombrowski 2010). By pushing for monitoring and stakeholder consultation mechanisms, CSOs can also help foster the creation of formal accountability mechanisms in the system of governance, particularly within public administration (for a fuller discussion, see Bernauer \& Gampfer 2013). In developing countries, governance gaps tend to be wide, given that systems of public administration have fewer resources to address sustainable development challenges. However, in engaging civil society in gap coverage, specific risks need to be recognised, such as the creation of dependencies and the crowding out of public policies (Chan et al. 2019). Although a CSO may have the status of a statutory organisation, which stipulates that they must be consulted on relevant policy developments and may therefore be in receipt of state funding, the fact that CSO interventions are often driven by short-term project-focused funding means that gaps may reappear once interventions are over, making long-term strategic engagement difficult. It is also important not to ignore the possibility that CSOs may use their skills and funding to pressure local governments and further their own policy preferences, which may not always align with local needs (Cook et al. 2017). There is increasing recognition among governance scholars that non-government actors are exerting greater levels of influence over governance systems and contributing in novel ways to governance processes, but that in doing so they may be actively pursuing their own policy agendas (Gouldson 2009). 
The fair consideration of different interests is particularly important in the face of climate change, given its differential effects on societal groups (Thomas et al. 2018). Furthermore, climate change is the typical example of a complex multi-scalar environmental problem, where mitigation and adaptation require a diversity of actors across the state-society divide (Lemos \& Agrawal 2006). In the area of climate change, non-state actors are taking an enhanced governance role across international down to local scales (Kuyper et al. 2018). CSOs participate with the state as actors in international climate change negotiations (Lane \& Morrison 2006, United Nations 1992), being recognised as an essential component of good governance (Banks et al. 2015). CSOs also participate as key agents in the implementation, monitoring, and evaluation of climate change policy (Haris et al. 2020). However, as climate change has become accepted by policy institutions and by state and non-state actors, in many cases the role of CSOs has shifted from being critical agents that provide bottom-up pressure on the government, demanding problem recognition and policy implementation, to state-partners developing and implementing strategies, threatening their legitimacy (Gough \& Shackley 2001).

There is a growing focus in the literature on the interdependence between civil society and the state, and the developing institutional relations that are emerging across governance scales. The state can govern 'through' civil society, but this also reminds us that civil society is constantly translating, interpreting, and resisting government policy. Such considerations call us to move beyond the simple binary of the powerful (but clumsy) state pitted against powerless (but flexible and innovative) civil society (Lane \& Morrison 2006). This suggests that, although CSOs are becoming important actors in shaping and framing climate change problems and solutions (Davidson \& de Loe 2016, Newell et al. 2012), their role and significance may be more complex than this. In short, CSOs need to be examined to ascertain if they have generated agency, gained access, are exercising authority and whether this is resulting in the alteration of climate change risks.

Yet, amidst these claims it is also important to recognise that the social and political history and context of individual polities are largely responsible for shaping institutional arrangements. These dimensions have deep historical roots (Putnam 2000). Thus, whether a society relies upon on market, non-profit, or state provision for social and other key services and the provision of public goods is heavily constrained by historical development and evolving societal patterns (Lane \& Morrison 2006). Indeed, institutional analysis has suggested that the size of civil society varies according to the level of government expenditure, and according to the disposition of the state to either cooperate with or control civil society (Lane \& Morrison 2006). This recognition calls for context-specific research. Chan et al. (2019) warn that, when studying the novelty of observed phenomena, the stubbornness of old practices can 
easily be underestimated. It is therefore vital to study not only the increasing number of non-state actions but also how consequential they are, whether they substitute unsustainable activities, and whether their scope is broad enough to generate systemic change (Chan et al. 2019). Specific knowledge will also be key to critically appraising geographically imbalanced outcomes of non-state actions. The case of Quintana Roo provides an opportunity to examine the role of CSOs in climate governance in a context of high coastal vulnerability and weak state presence. It also presents a case where a thick network of CSOs has emerged.

\section{Methods}

To explore the role of CSOs in climate change governance in the state of Quintana Roo, Mexico, a case study approach was employed (Gerring 2007). Qualitative fieldwork involved stakeholder focus groups, in-depth face-to-face and online interviews, direct observation, and document analysis to examine key actor perceptions, attitudes, and interests. The study took place along the coastal corridor of the State of Quintana Roo (Figure 1) throughout 2017-18.

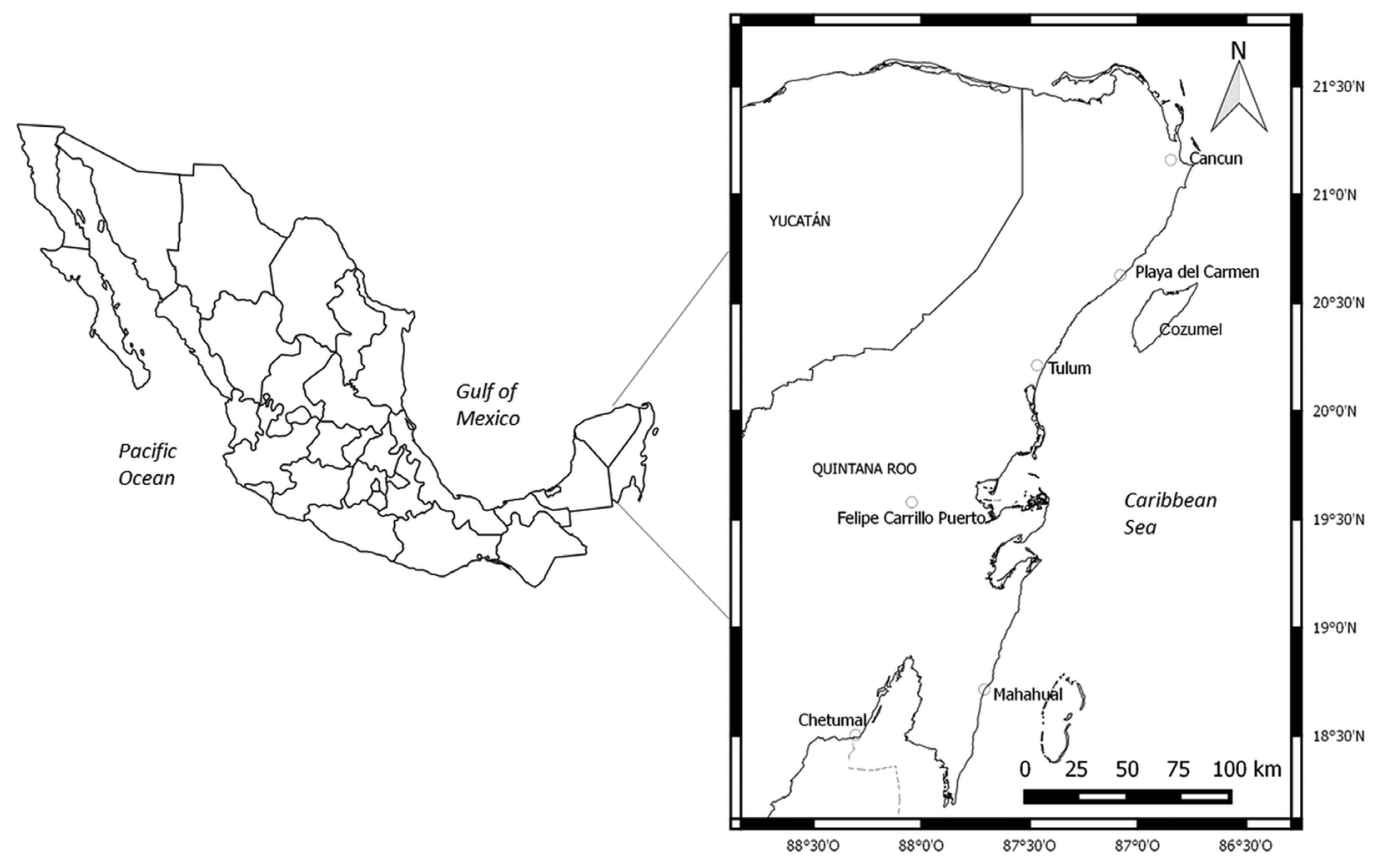

Figure 1. Map of Quintana Roo showing the location of the study sites. 
In addition, during 2020 a series of online interviews with key actors from CSOs were held. At the beginning of the study, the authors received ethical approval from their respective universities. Four stakeholder focus groups were held in Tulum, attended by twenty-four participants in all; and one was held in Bacalar, attended by seven participants. The focus groups were held in March 2017 and drew representatives from local and regional government, research institutions, representatives from the water, forestry, and ecotourism sectors, and from CSOs. In May 2017, three semi-structured interviews were conducted in Cancún and Playa del Carmen with key environmental organisations operating in the region. In July 2020, ten online semi-structured interviews with key CSOs were conducted using the video conferencing application Meet by Google. Interviews explored the different organisations' actions, motivations, role in public policy formulation, implementation, and monitoring. All the interviews were recorded and transcribed with the consent of participants. Transcripts were analysed through Atlas.ti 8 for Windows (Scientific Software Development $\mathrm{GmbH}$ ), using the qualitative content analysis method (Schreier 2012) based on a deductive coding strategy (Mayring 2020, Hsieh \& Shannon 2005). These interviews were conducted in Spanish and subsequently translated by the authors. In addition, documents from $\mathrm{CSO}$ web pages provided background information, together with direct observations, for the internal validity of results through data triangulation. The research was also informed by the scientific literature.

\section{Governance of climate change in Mexico}

Mexico joined the UN Framework Convention on Climate Change (UNFCCC) in 1992. However, during the 1990s, addressing climate change was not given priority by the Mexican government. It was not until 2005 that Mexico established the Intersecretarial Commission on Climate Change (CICC, Spanish acronym), tasked with mainstreaming climate change in economic development policy. Hosting the 16th Conference of the Parties (CoP16) of the UNFCC in Cancún in 2010 had a significant effect. Mexico is widely credited with helping to rescue faltering international efforts at the time to address climate change, although the lack of corresponding action addressing climate change domestically was noted.

A national climate change law, The General Law on Climate Change (LGCC, Spanish acronym), was passed in 2012. ${ }^{1}$ The LGCC was the first of its type for lowand middle-income countries and one of the most comprehensive in the world at that

${ }^{1}$ Gaceta Parlamentaria, año XV, número 3489-IV, jueves 12 de abril de 2012, available online at: http:// gaceta.diputados.gob.mx/Gaceta/61/2012/abr/20120412-IV.html\#DictamenaD1 
time, setting high targets for mitigation and aiming to coordinate the work of federal, State, and municipal governments and the actions of civil society and the private sector (INECC 2019). The LGCC contains many provisions relating to mitigation, including a mandate to reduce emissions of carbon dioxide by 50\% below 2000 levels by 2050 . Furthermore, it stipulates that $35 \%$ of the country's electricity should come from renewable sources by 2024 and requires mandatory emissions reporting by the country's largest polluters. Mexico became the first developing country to present its unilateral commitments to greenhouse gas emissions, even though it was not obligated to reduce its emissions under international agreements.

Mexico has created an appropriate regulatory and institutional framework for developing regional and local climate change adaptation plans. Several local adaptation programmes have also been initiated nationwide (Sosa-Rodriguez 2014). However, administrative traditions have not proved conducive to the emergence of governance approaches that can effectively address the problems of climate change. Plans to address climate change through enhancing relationships between the state, market, and civil society have faltered, despite the central role that this relationship plays in the government's strategic planning.

Despite regulatory, institutional, and planning responses, climate change policy in Mexico is restricted by the premise that implementation should not impose a burden on national economic growth and that the country's competitiveness in international markets should not be hampered (Gobierno de la República 2013). There are also considerable path dependencies that hinder transition, particularly in the energy sector where monopolies, perverse subsidies, and inefficiency in energy use act to disincentivise the transition to clean energy (Ibarrarán Viniegra et al. 2011, Sosa-Núñez 2015). In fact, a recent energy law passed in May 2020 priorities the use of fossil fuel power plants at the expense of renewable energies and puts Mexico on a path that is even more inconsistent with the steps needed to achieve the Paris Agreement's $1.5^{\circ} \mathrm{C}$ limit (Climate Action Tracker 2020). The failure to act effectively to ensure forest conservation has also hampered efforts to address climate change (Rantala et al. 2014).

Policy weaknesses are also noticeable, including in the climate strategies, which lack concrete lines of action and instruments or mechanisms to carry out the proposed objectives (Ibarrarán Viniegra et al. 2011, von Lüpke \& Well 2020). It has also been argued that, like most countries in the region, while Mexico has produced national climate action plans and at least one emissions inventory, these instruments have been used exclusively for reporting purposes, and have not been translated into specific planning or monitoring actions (EuropeAid 2009). Thus, it is not surprising to find that, from 1990 to 2017, emissions in Mexico saw an increase of 64.7 per cent, with an annual growth rate of 3.2 per cent resulting from higher energy use (Climate Action Tracker 2020). 


\section{Governance of climate change in Quintana Roo}

Quintana Roo is one of the three States participating in the Yucatan Peninsula regional climate change initiative. In 2016, the States of Campeche, Yucatan, and Quintana Roo signed the Sustainability Agreement for the Yucatan Peninsula, which has specific activities and goals for climate change mitigation and adaptation (IIED 2019). Actions are also supported at the State level, as addressing climate change is, in part, a devolved competence within Mexico's federal structure. In Mexico, States oversee the elaboration and implementation of regional development plans, drafting policies on the use of natural resources, implementing ecological controls, and managing State natural protected areas (NPAs). The State legislature can create its own laws on environment, urban development, and civil protection, but they align with federal legislation.

In 2013, work started in Quintana Roo on the formulation of a State climate change law, Ley de Acción de Cambio Climático del Estado de Quintana Roo, which requires a State action plan (PEACCQROO), and created a Climate Change State Commission. ${ }^{2}$ The State Development Plan 2011-2016 focused on the need to identify climate change vulnerabilities and formulate adaptation measures. It also highlighted the value of adopting a regional focus, covering the Yucatan Peninsula, and the importance of involving all sectors and stakeholders. ${ }^{3}$ The current State Development Plan 2016-2022 begins to address the need for economic diversification, and how to promote more ordered growth in keeping with environmental sustainability (UN Environment 2017).

Like Mexico, Quintana Roo has weak governance structures and limited implementation capacity. This weakness constitutes one of the main challenges for addressing climate change and implementing the many policies that have been formulated (Fosci 2013). While Constitutional reform in 1999 gave municipalities greater autonomy, the State remains unable to implement significant actions without federal support, which is not always forthcoming (Rantala et al. 2014). States and municipalities remain highly dependent on federal transfers. In addition, responsibility is highly fragmented, with the federal government having control over marine areas and a narrow strip of coastal land, while the State in Quintana Roo holds control over land more than twenty metres from the sea and is the principal actor in developing and enforcing ecological land-use plans. Furthermore, the State controls the municipal tax rates and must approve all municipal development plans. This means that lower levels of government can easily be controlled by actors operating at higher levels.

${ }^{2}$ http://www.opb.gov.mx/ opb2011/

${ }^{3}$ http://www.qroo.gob.mx/ qroo/planquintanaroo/ 
While an effective climate change strategy involves coordination with most departments, sectors, and across multilevel governance scales, the structure of governance in Mexico acts against this coordination. Local governments often lack decisionmaking powers over key policy issues relevant to addressing climate change, such as transportation, energy, and infrastructure. In addition, departments in charge of climate change often have limited budgets and lack political influence within the government structure (Satterthwaite \& Dodman 2009). Corruption within the system of public administration in Mexico, across all levels, also risks illegal division and sale of land, and bribery in planning.

Weaknesses in the State and in governance in Quintana Roo provide both the need for and the opportunity for CSO engagement. Recent years have seen the thickening of civil society in the State, and the number of NGOs and business interest associations has grown dramatically (Baker et al. 2020). Furthermore, a small, but growing, local entrepreneurial class has emerged, and the State also boasts several academic institutions, including the University of Quintana Roo and El Colegio de la Frontera Sur (ECOSUR) in Chetumal. The State also has experience of utilising participatory planning processes, given that, for example, river basin councils, and the development plans all involved participation as a federal prerequisite. In addition to the participatory processes developed locally, there are close personal relationships that encourage cooperation between different government sectors and with civil society and the private sector.

\section{The role of civil society organisations in climate change governance in Quintana Roo}

According to different databases provided by CSOs, in Quintana Roo there are approximately fifty organisations working on different aspects of conservation, environmental management, and governance. The diversity of organisations is wide, from small ones working on very local issues, to large international NGOs such as The Nature Conservancy. Without covering all the areas in which these CSOs work, these organisations carry out activities on issues of conservation, natural resource management, development, fisheries, forestry, tourism, and education and outreach, in diverse ecosystems such as marine, coastal, terrestrial, aquifer, among others.

\section{Working on climate change}

According to the interviews conducted, while many CSOs do not deal directly with the implementation of climate change adaptation or mitigation actions, most groups 
address climate change, 'in a more tangential way' (Interviewee IC). A few CSOs mentioned that climate change is one of their main lines of action, although all acknowledged that they directly or indirectly work with climate change because of the high vulnerability of the region. One highly organised group, with a long-standing engagement in the State, admits: 'on climate change, this project that we submitted ... would be our first' (Interviewee IC). However, there are specific international groups operating in the State that address climate change as a core part of their operations:

[We have] a very defined strategy for confronting climate change. In the case of Mexico and the Mexican Caribbean in particular, we are working with coastal resilience, how to build the resilience of communities, both human communities and biological communities. (Interviewee ID)

For instance, for several years this particular ENGO (environmental NGO) has been implementing a programme called Coastal Resilience that promotes the restoration and conservation of natural coastal systems, such as dunes, mangroves, and reefs, to protect against the impacts of climate change. Another CSO is directly taking action to address climate change issues through the eradication of invasive species on islands, such as Cozumel, with the intention of subsequently restoring these ecosystems and thus mitigating the effects of climate change. Another CSO promotes regulatory responses and, acting in collaboration with the Interamerican Association for Environmental Defence (AIDA), was able to enhance the legal protection provided for the Yum Balam Protected Area in Quintana Roo by filing an amicus curiae brief before the Supreme Court of Justice. The coastal ecosystems that make up the Yum Balam Protected Area, in addition to their environmental value, also have an important role in addressing climate change. In addition, some of the organisations interviewed have been extensively involved in designing and constructing policy for reducing emissions from deforestation and forest degradation (REDD+), plus the enhancement of carbon stocks at national and subnational levels. REDD+ plays a role within global efforts to mitigate climate change from the forestry sector, as it seeks to slow down, stop, and reverse the loss of forest cover and increase in carbon emissions.

Recognition of the problem of climate change for the coastal community is growing, with one group acknowledging that 'in Cozumel it is already very dramatic because there are already many people, there are already more than eighty thousand people living at sea level' (Interviewee IE). Similarly, another group demonstrates its knowledge of the cascading vulnerabilities of the Yucatan, with climate change expected to bring:

Changes in rainfall, if there is no rainfall, then you are going to have an aquifer with saline intrusion; if there is more rainfall you are going to have flooding as just happened with Cristobal [a recent tropical storm that hit the area in June 2020]; if you have a rise 
in sea level, erosion of beaches, and that has an impact on tourist infrastructure, which in the case of Quintana Roo is the main economic sector-but on the other hand climate change is also affecting the mangroves which are the fish nurseries and this is also affecting fishing. In short, there are a series of conditions which show you that the Yucatan Peninsula is vulnerable. ... Right now, we are working on a proposal to implement adaptation actions based on ecosystems or natural solutions, precisely to address these vulnerabilities in terrestrial, coastal, and marine ecosystems. (Interviewee IJ)

The coastal zone is seen as particularly vulnerable to climate change because of the ecological destruction that has accompanied the area's rapid ad hoc development, that lacks strategic and integrated planning, and which has reduced the capacity of the system to absorb climate change shocks:

We continue to build in the coastal zone with bad practices, we continue to deteriorate the natural protection that we already have - mangroves, dunes, and reefs - and then the storms come stronger and stronger ... climate change increases the degradation of the systems that is already happening and increases the impact and flooding ... (Interviewee ID)

Similarly, another group stresses that:

You can't separate climate change here from the impact of tourism; the biggest risk for the whole area is bad tourist development. I can mention hotel areas where there are no drains, and the hotels continue to discharge their ... [waste] waters to the sea. (Interviewee IF)

This link between coastal development and climate vulnerability makes addressing climate change more complex, because it means that the task also has to address systemic matters. This is acknowledged by several groups, and is clearly reflected in the statement 'in reality adaptation to climate change is something that has to be transversal to all activities, all sectors particularly our regions' (Interviewee IA). At the same time, the fact that the main form of economic development, tourism, is acutely dependent upon the maintenance of critical ecosystem services in the region, in turn creates opportunities for action, a matter that we return to below.

The fact that the coastal area is highly vulnerable to climate change also means that groups working on different aspects of coastal management are indirectly dealing with climate change matters:

... in the Riviera Maya, precisely Akumal, is one of the sites of greatest erosion on the coast of Quintana Roo ... and I imagine that this affects, or is reflected in, the different scenarios of climate change, above all in the rise in sea level. ... Akumal has a very narrow strip of beach, so all the hotel infrastructure, condominiums, and homes are subject to the direct interaction of waves, storm surges, swells, normal coastal changes or processes, loss and gain of sediments, and ultimately climate change. (Interviewee IH) 
Indeed, there is a sense in which the issue of climate change, although only dealt with indirectly in projects or activities to date, is in fact a core, underlying, challenge to which all their work is addressed. For example, a group, working on cultural heritage, tell us that their work in fact forms part of climate change mitigation actions, even if it is not directly specified in this way:

We work from the local and regional social fabric, and we approach and connect from that voice, so we have a presence in reflections on climate change ... [as] ... we are generating from the appropriation or re-appropriation of the cultural and natural value of heritage, the possibility of sustainability of rural communities ... of transformation towards sustainable practices, conservation agriculture and ... safeguards for self-consumption of mainly native maize seeds. (Interviewee IG)

Nevertheless, the same group expresses concern that directly focusing attention on climate change may risk taking actions too far away from community needs:

... we avoid addressing large complex concepts that generate a nebula in ... the attention to needs [within] communities. ... So, we work directly with climate change mitigation strategies; however, we are very transparent in evolving our language from the language of the communities themselves. (Interviewee IG)

Groups also pointed out that there are different ways to deal with the problem of climate change, over and above addressing it in a substantive manner, either directly or indirectly. It is also about giving voice to people and enhancing their capacity to act in the face of climate threats. One development organisation plainly states that 'we know that participatory and collaborative models are indispensable for the sustainability of transformations' (Interviewee IG). This is more so given concerns about the slow or even absent pace of government response, even if the manifestations of climate change are visible as urgent.

\section{Activities undertaken}

Data gathering is a typical activity of a CSO, designed to support policymaking directly, but also indirectly by underpinning arguments in support of more government regulation and involvement. Several of the CSOs are engaged in monitoring and data collection, which they share directly with public authorities, playing an important role in capacity building and knowledge sharing in relation to the emergence of risks and impacts generated by climate change. For example, one group explains their motivation is to '... contribute with information that influences decision-making' (Interviewee IH). Another example is provided by an ENGO: 
[We] made a projection of how the hurricanes are going to change over the next hundred years. It is a very complex and complete study and we arrived not only at the physical assessment of how much the flooding and the swell in the reefs are reduced, but also at the economic value. (Interviewee ID)

Many of those working for CSOs come from a natural science background, and scientific data gathering and sharing lend them authority in the governance system. One group explained that '[We are] an NGO or CSO that publishes a lot because we are based on science, we have more than 130 [scientific] articles' (Interviewee II). Another group, directly working on the impact of the rise in sea level arising from climate change, explains:

We made the diagnoses, we have a group of mathematicians within the organisation, compact and very good at modelling ... so, just as they are involved in data management for conservation, we are also involved in the issue of sea level rise modelling in the Caribbean. (Interviewee IE)

Many times, this scientific work is carried out in collaboration with academia, including Mexican universities as well universities from abroad. Another group explains that their role '... is to provide data, we generate hard data, scientific data, we have databases available, our philosophy is free access to information ...' (Interviewee IA). Knowledge sharing and allowing free access to data are partly driven by the recognition that federal agencies, although they have the mandate to undertake inspections and monitoring, lack sufficient funds and capacity to undertake these tasks:

The State institutions that deal with environmental problems are completely weakened, they have neither financial nor human capacities to be able to operate, all of them, that is, our environmental apparatus is fatal, in a very bad state. (Interviewee IJ)

Furthermore, in recent years, the position of these agencies has deteriorated even further, particularly under federal government austerity programmes 'They're overstretched, they're taking more and more of their budget' (Interviewee IB), and as detailed in one interview:

Bearing in mind the federal level, for instance, the Minister for the Environment has had a cut on their budget for almost 40 per cent for the last three years, so it means that they have less people to hire and they have less expertise. ... So, it means that [while] they need to request the technical opinions according to law ... they don't have money to hire the expertise for reviewing the statement. (Interviewee IL)

Nature protection is particularly hard hit, 'I work directly with CONANP [Comisión Nacional de Áreas Naturales Protegidas], which is without resources even to be able to do control and surveillance' (Interviewee IJ). In this context, organisations also help to strengthen the capacity of State institutions and support federal authorities fulfil their monitoring obligations: 
We have contributed to establishing some monitoring schemes for the aquifer, in this specific case we have two studies in Tulum, we were able to acquire a parametric probe, which we use to see water quality. (Interviewee $\mathrm{IH}$ )

As well as support for implementation and monitoring, groups also work to support new policy developments. One group is working on an action programme for endangered species, and many of the organisations work to bring better regulation of environmental issues. The use of scientific data as leverage for regulation is notable. Groups also believe that, through their scientific data gathering and monitoring of information, they have built up good relationships with federal authorities. Thus, the scientific work conducted by a CSO not only lends legitimacy to their engagement in governance but can also give them a seat at the policy table.

\section{Civil society organisation engagement across governance scales}

\section{Community involvement}

Several of the CSOs interviewed have developed strong ties at local, community, level. These ties can form through engagement in educational activities, which includes a component of awareness raising, which in turn forms part of a wider agenda of civil society development. A developed civil society goes hand in hand with the capacity to participate in public policy decision-making, thereby allowing a community to have a say in decision-making that shapes their lives. One group is particularly clear about this role, saying 'We are a civil society organisation - our mission is to promote the participation of all stakeholders to achieve sustainable or sustained marine conservation and fisheries' (Interviewee II).

This is more than just an interest in supporting participation through bringing together stakeholders on an ad hoc basis. Democratisation of governance, especially through access to information, is also a major motivating factor. One CSO, for example, argued that one of their objectives in starting a local Smart Water project was to address the 'issue of governance and democratisation of information, that as a citizen you can know what quality of water is coming to you when you open the tap' (Interviewee IC).

For some groups, the democratisation of governance is grounded on a moral commitment to promote environmental justice. This is reflected in their desire to give voice to the marginalised and those who are not normally considered in public policymaking. This work brings CSOs directly into the public policy arena and into the orbit of public authorities and public administrators, across multiple levels of governance. 


\section{Institutionalisation of engagement across multilevel governance}

All CSO organisations we interviewed had built up a range of relationships with public authorities, across multilevel governance structures, operating from the federation, to the State, and down to the local, municipal, levels. Relationships range from having informal contacts, often at a personal level, through to membership of official bodies and boards. However, organisations differed in their opinion as to why they thought that this engagement was necessary, some seeing themselves as undertaking work that ought, in an ideal case, to be undertaken by the State, and others seeing their role as bringing additional, often instrumental value to policymaking and implementation, such as through providing information, policy options, and scientific data.

Speaking about nature protection, one group believes that 'CONANP should be totally responsible for everything we are doing' (Interviewee IB), and similarly another holds that 'we are covering gaps that should probably be covered by the government, but we are in difficult situations and that is why' (Interviewee IA). A similar sentiment was expressed by another group: 'So I think that there are things that the NGOs end up doing that the government should do more' (Interviewee IC). Some see themselves as co-engaged, through a sense of shared responsibility with the legally designated authorities:

Well, I am convinced ... that we cannot do all the work alone. I am convinced that the work of conservation and the use of resources must be multi-sectoral; it is a collaborative process where all sectors must do their part ... (Interviewee IJ)

Others see that their role, rather than accompanying the state in the fulfilment of their legal obligations, or filling in for an absent state, is to act as a catalyst and a facilitator, bringing together private and public interests to galvanise action. A recurring theme is that CSOs act as the generators and managers of strategic alliances:

One of our most important components is the creation of strategic alliances. ... Flowing with different actors, we are facilitators of networks, of alliances, of bringing actors together and facilitating those processes. (Interviewee IJ)

CSOs are also seen as having a critical role to play in giving voice to different viewpoints, with a bearing on policymaking, an argument often made in the literature, as discussed above:

I think that there are things that the NGOs end up doing that the government should do more, but there are others that the government should not do, because in the end we are an independent viewpoint and another sector of society, so we will always have a niche for participation and opinion ... so I think there is a role that can never be replaced by, the role that civil society organisations play. (Interviewee IC) 
Links with federal government proved strong: in particular, those forged with federal authorities charged with the management of environmental affairs, including water. One group provided an example of a typical portfolio of relationships held by a CSO:

We have a collaboration, at the federal level—it is a lot with CONANP ... also with ... $S E G O B$ [Secretaría de Gobernación], with SECTUR [Secretaría de Turismo], with FONDEN [Fondo de Desastres Naturales], SEMARNAT [Secretaría de Medio Ambiente y Recursos Naturales]. Then at the State level we also work very closely with the environmental sector of Quintana Roo, both at the level of the Secretary of the Environment and at the level of the technicians, both on climate change ... we have a collaboration agreement signed with them, and now also with SEDETUR [Secretariat of Tourism of Quintana Roo]. At the municipal level ... the response has not been very good and then ... they change every three years - at the municipality, if there is a need, we inform, but we do not seek that relationship. (Interviewee ID)

Whether an organisation works at federal level or below is thus shaped by how the division of competences across Mexico's multilevel constitutional structure is organised:

We only work with federal authorities, we work at sea all the time, so we only have to deal with Marina, CONAPESCA [Comisión Nacional de Acuacultura y Pesca] and CONANP, who would be responsible for doing what we are doing (Interviewee IB)

In contrast, other organisations explain that they predominately work at State level, and this ranges across involvement in State councils and advisory boards. For example, an organisation is on the social development commission of the State government, where it has built up 'a fluid, transparent relationship' (Interviewee IG). Another group explains it simply when it says 'We are on practically all the advisory boards that deal with island territories' (Interviewee IE). However, some groups found that the State level was difficult to penetrate. One group explains that the formality involved, and the requirement for official invitations, inhibit participation and cooperation. In contrast, the local, community level is seen as more accessible (Interviewee II).

Groups also work at the municipal level, although this can mean their engagement overlaps across governance scales. Development of strong links with the municipal level of government is made both necessary and possible by virtue of the weak capacity of local government:

We always operate in coordination, or at least on the basis of a very informed intervention, at the municipal level - where we understand that there is a lack of training throughout the structure of municipal governments and they are very weak, that is, they are very weak at the budgetary level, but also at the level of capacities for management and governance, they have very few tools, they still manage a lot because of political patronage. (Interviewee IG) 
Groups also found that personal relationships are critical, particular at the local level. Connections with environmental policy champions were particularly important in driving policy forwards. However, groups are keenly aware that such champions operate in a wider political context, which may restrict their capacity to act. Here, it is clear that the political opportunity structure does impact upon the capacity of environmental champions to act. At a more general level, groups can also express frustration, especially about the slow pace of change:

I work with CONANP, with CONAPESCA, with INAPESCA [Instituto Nacional de Pesca y Acuacultura] — nothing has changed, they don't solve anything quickly. ... I was talking to people from INAPESCA, he says, 'it's that there's no money', well, it's the same thing I've heard for thirty years, they never have money, never, why should this time be any different. (Interviewee II)

Thus, despite the extent of relationships, judged by range and numbers, that have built up between CSOs and public authorities, there is also scepticism about this engagement. A representative from one group describes that, while they participate in some public bodies, especially advisory councils, and technical and consultative councils:

You can see that there is an infinite number of councils ... 'this is a time taker'.... We have had terrible experiences ... we have no memory, we say the same thing over and over again, we sell the same biscuit ... the government never has a solution. (Interviewee II)

Another interviewee expresses frustration about the government's planning efforts due to lack of real action:

I think that we should stop making plans, that is to say, we should stop making workshops and plans, and we need more will, but clearly from the private sector, and if it's not voluntary will, there should be more enforcement. (Interviewee IA)

Instead, the organisation expressed a strong preference for avoiding this form of engagement, choosing to work 'in small local committees' (Interviewee II). Here, they can see a real option for change.

\section{Risks of engagement}

Engagement is also not without risk, especially when groups face intimidation and harassment. Mobilisation of civil society, with its focus on collective action for the common good, brings groups into conflict with prevailing powers in Mexico. The main reason, according to virtually all interviewees, is corruption: 
In the States, and then in the municipalities, it's very complicated, really the level of corruption, I believe that this is the central issue in Mexico-again in the example of Tulum, we feel frustration and sadness and anger to see the people who work in the municipality, their interests, the corruption, it is a very, very strong issue. (Interviewee IC)

Corruption directly affects the capacity of groups to address the particular vulnerabilities of the region in the face of climate change, given that addressing coastal risks is central to climate change adaptation and mitigation and given the reductions in natural defences caused by tourism development:

There is a lot of corruption, corruption in the region is very serious, it's very important in the sense that it has a lot of power, we are facing very big powers, right now there is a construction site of a hotel that was built in a turtle nesting area, in the dune, in the mangrove and it has an order from a judge to stop the activities, the activities were not stopped, they continue ... if we continue to destroy the reef, the dune, the mangrove and everything, can we have plans to adapt to climate change? (Interviewee IA)

Part of a CSO's effort, therefore, is to work to counteract the impact of this corruption on environmental governance, and more generally to promote order in public life. Here CSOs see themselves as playing a vital role in ensuring that policy is made in the best interests of society and the environment, and that CSOs act as a countervailing force in the face of bribery. In this fraught context, establishing horizontal relationships, within and between CSOs becomes important for building networks of support and solidarity:

We have very good relations with important organisations and actors or individuals who have also done environmentalist work for many years ... we have joined in and supported, so to speak, demonstrations in the media, as well as legal proceedings, denunciations, all that sort of things that could help ... we participate with a consortium of more than sixty organisations in the Mesoamerican Reef System. (Interviewee IH)

This view is not least because groups see their role as one of supporting the growth of civil society and the democratisation of the public sphere. NGOs are also well linked internationally, a link that puts them at a distinctive advantage when it comes to leveraging funds in support for activities, especially targeted projects at the local level. However, donor dependency can bring risks, especially in relation to donor-driven agenda setting. Speaking about 'the dark side of the environmental movement', one group explains their concerns about becoming:

... very dominated by foreign agendas, that's very worrying and one lives it ... what they call it in English 'donor driven': I'm going to give you a fund, but you're going to dance to my tambourine. (Interviewee IE) 
But groups also face other donor-related difficulties, including that donors often only provide support at project level, funding that is frequently short term. Funding can sometime be of a more local origin, with groups working directly with local economic actors in support of local activities. The hotel sector was pointed to by many groups as both a critical source of environmental problems and as a funder of remedial action, as one group describes:

You have a very large potential in the Yucatan Peninsula, big businessmen, the hotel sector, which could be putting in resources that go directly to the field. ... We are creating a regional fund for the Yucatan Peninsula, to be able to converge with these investments or to align public and private investments. (Interviewee IJ)

Donor dependency poses fewer risks when organisations work with local actors. As mentioned earlier, climate change presents a direct threat to the coastal tourism industry and thus the interests of CSOs and the tourism industry are closely aligned. As a result, collaboration on coastal protection measures with private economic interests is growing. For example, one group mentions:

We already know how to do it [but the question is] who pays for it, right-well let's go to the hoteliers that are interested ... in protecting their beaches from coastal erosion, which is the new phenomenon of loss ... well, you contribute locally, right? the hoteliers or tour operators put in boats, the other hotelier puts in petrol ... (Interviewee ID)

One group provides another rationale for this collaboration between CSOs and economic actors:

[there is a] tendency to seek to make the state ... responsible for a certain guarantee of rights ... today of the one hundred largest economies in the world fifty are companies, then, obviously the distribution of decision-making to shape or polish, to give shape to society, is not necessarily in the hands of states or the configuration of inter-state cooperation instances, but it also has to do with other sectors of society that are having a lot of power. (Interviewee IG)

This turns our attention to the need to draw out the significance of these findings for our understanding of the role of CSO in climate governance.

\section{Conclusion: the role of CSOs in climate governance}

Quintana Roo in Mexico presents a case where CSOs actively engage, both formally and informally, with public authorities to address climate vulnerabilities. While not all groups deal with climate change directly, recognition of the pervasive and encompassing nature of the climate challenge means that attention also has to be paid to those 
organisations that deal with other, related, issues, such as environmental and development issues, including specific species and habitats. This wider view gives a better picture of the role of CSOs in climate governance.

In the case of Quintana Roo, CSOs were found to provide scientific and technical expertise to underpin implementation and monitoring of existing policy, but also acted as advocates of new legislation, particularly for protected areas. In this sense, CSOs play a complementary or supplemental rather than substitutive role, where government still functions as a regulatory actor-and indeed are expected and encouraged to do so by CSOs. Furthermore, CSOs were also shown to act as boundary organisations, serving on the interface between communities of experts and public policy decision-makers (Cash et al. 2003). More specifically, they have functioned as epistemic communities, forming critical bridges that serve as conduits for information flow (Haas 1992). Over time, CSOs have built solid and trusting relationships with local communities, with governmental agencies, and with federal, State, and municipal governments, playing an essential role in the capacity building of an array of key actors. In part, this acceptance has been based on the value of the contribution that CSOs have made, often to specific issues, and in support of the public management of climate vulnerabilities. Their engagement has also lent input legitimacy to government processes, while, in turn, strengthening the credibility of CSOs as legitimate actors operating within the climate governance system. This participation is in part driven by the failure of central government to ensure that the constitutional arrangements that give power and responsibility downwards in the system of multilevel governance to State and municipal actors is matched by the provision of corresponding resources to enable them to exercise their duties. In this context, CSOs have had to fill in for an absent state (either federal or devolved), helping to close the 'capacity gap', which is particularly evident as one moves down the system of multilevel governance, a gap that prevents tiers of governments from effective management of climate change (Cook et al. 2017).

The research also revealed that structures do affect what CSOs can achieve. Especially under conditions of weak administrative capacity and corrupt government, certain enabling institutional conditions are needed, such as a willingness on the part of authorities to open up their administrative systems to participatory processes, the existence of actor networks, the establishment of personal links and contacts, and the presence of environmental policy champions. Globally, it is not uncommon for CSOs to have to work under conditions of state corruption and to be hampered by lack of access to sufficient resources. By examining how CSOs operate under these conditions, this article contributes to a deeper understanding of the enabling factors that promote successful CSO engagement. 
Yet, in the context of government corruption and the lack of transparency and accountability in the management of public affairs, CSOs remain wary of getting too close to government. Furthermore, there are considerable ideological barriers to the involvement of CSOs in climate governance, especially when the model of economic development that is promoted both creates climate vulnerabilities and coalesces vested interests around its continued expansion. The coastal zone of Quintana Roo is particularly vulnerable to climate change because of the ecological destruction that has accompanied the area's rapid development, which has reduced the capacity of the ecological system to absorb climate change shock. The direct link between coastal development and climate vulnerability makes addressing climate change more complex, because it brings attention to the need for a new economic approach. At the same time, it also sees the emergence of business interest associations seeking to address climate vulnerabilities caused by tourism development and act to support the natural resource base upon which tourism, and their livelihoods, depend. This creates complex contexts in which CSOs emerge, networks develop, alliances are formed, and barriers to effective engagement begin to erode. The collaboration forged between actors operating across civil society and the business sector has enabled the formation of a buffer against climate change and supported actions in pursuit of more sustainable futures.

We have used 'hybrid governance' as a conceptual lens in this article to explore climate governance. This has enabled us to examine the dynamics involved in, and consequences of, private actor mobilisation in collaboration with state agency. While the literature on hybrid governance has been largely restricted to a focus on hybrid arrangements that involve formal partnerships, this article has paid attention to informal relationships, which emerge at local scale through practice. This shift of focus to governance arrangements existing outside of formal institutionalisation has revealed new insights into the capacity of the system to respond to climate change. Whether or not the process of what Purcell (2009) calls the 'welding together' of disparate interests improves governmentality remains in question. Hybrid formations do improve outcomes, as demonstrated in this article. Yet, as Purcell remind us, 'the idea that economic growth trumps other concerns remains the dominant common sense' (2009: 315) even in the face of the evident threat of climate change. Whether CSO actions can become a dominant, counterbalancing force is, as yet, undetermined.

\section{Acknowledgements}

This research was funded by the British Academy, GCRF Sustainable Development Programme, under the project 'Integrating Policies on Land Use Changes and Coastal 
Zone Management to Deliver Food Security and Environmental Conservation: The Role of Private and Public Governance'. BAO acknowledges the support of the Universidad Nacional Autónoma de México (UNAM), Programa de Apoyo a Proyectos de Investigación e Innovación Tecnológica (PAPIIT), UNAM-PAPIIT IA301120.

\section{References}

Bäckstrand, K. (2006a), 'Democratizing Global Governance? Stakeholder Democracy at the World Summit for Sustainable Development', European Journal of International Relations, 12(4): 467-98. https://doi.org/10.1177/1354066106069321

Bäckstrand, K. (2006b), 'Multi-stakeholder Partnerships for Sustainable Development: Rethinking Legitimacy, Accountability and Effectiveness', Environmental Policy and Governance, 16: 290-306. https://doi.org/10.1002/eet.425

Bäckstrand, K. \& Kuyper, J.W. (2017), 'The Democratic Legitimacy of Orchestration: The UNFCCC, Non-state Actors, and Transnational Climate Governance', Environmental Politics, 26(4): 764-88. https://doi.org/10.1080/09644016.2017.1323579

Baker, S. \& Chapin III, F. (2018), 'Going Beyond "It Depends:” The Role of Context in Shaping Participation in Natural Resource Management', Ecology and Society, 23(1): 20. https://doi.org/10.5751/ES-09868-230120

Baker, S., Ayala-Orozco, B. \& García-Frapolli, E. (2020), 'Hybrid, Public and Private Environmental Governance: The Case of Sustainable Coastal Zone Management in Quintana Roo, Mexico', The International Journal of Sustainable Development and World Ecology, 27(7): 625-27. https://doi.org/10.1080/13504509.2020.1722764

Banks, N., Hulme, D. \& Edwards, M. (2015), 'NGOs, States, and Donors Revisited: Still Too Close for Comfort?', World Development, 66: 707-18. https://doi.org/10.1016/j.worlddev.2014.09.028

Bernauer, T. \& Gampfer, R. (2013), 'Effects of Civil Society Involvement on Popular Legitimacy of Global Environmental Governance', Global Environmental Change, 23(2): 439-49. https://doi.org/10.1016/j.gloenvcha.2013.01.001

Brooker, E.E., Hopkins, C.R., Devenport, E., Greenhill, L. \& Duncan, C. (2019), 'Civil Society Participation in the Scottish Marine Planning Process and the Role of Environmental Non-governmental Organisations', Journal of Environmental Planning and Management, 62(12): 2101-23. https://doi.org/10.1080/09640568.2018.1532876

Cash, D.W., Clark, W.C., Alcock, F., Dickson, N.M., Eckley, N., Guston, D.H., Jäger, J. \& Mitchell, R.B. (2003), 'Knowledge systems for sustainable development', Proceedings of the National Academy of Sciences, 100(14): 8086-91. https://doi.org/10.1073/pnas.1231332100

Chan., S. et al. (2019), 'Promises and Risks of Nonstate Action in Climate and Sustainability Governance', WIREs Climate Change, 10: e572. https://doi.org/10.1002/wcc.572

Climate Action Tracker (2020), Mexico. https://climateactiontracker.org/countries/mexico/

Cook, N.J., Wright, G.D. \& Andersson, K.P. (2017), 'Local Politics of Forest Governance: Why NGO Support Can Reduce Local Government Responsiveness', World Development, 92: 203-14. https://doi.org/10.1016/j.worlddev.2016.12.005

Davidson, S.L. \& de Loe, R.C. (2016), 'The Changing Role of ENGOs in Water Governance: Institutional Entrepreneurs?', Environmental Management, 57: 62-78. https://doi.org/10.1007/s00267-015-0588-8 
Dombrowski, K. (2010), 'Filling the Gap? An Analysis of Non-governmental Organizations Responses to Participation and Representation Deficits in Global Climate Governance', International Environmental Agreements, 10: 397-416. https://doi.org/10.1007/s10784-010-9140-8

EuropeAid (2009), 'Climate Change in Latin America. European Commission-Development Cooperation in Latin America', Europe Aid, Belgium.

Fosci, M. (2013), 'The Economic Case for Prioritizing Governance over Financial Incentives in REDD+', Climate Policy, 13: 170-90. https://doi.org/10.1080/14693062.2013.745112

Gerring J. (2007), Case Study Research: Principles and Practices (Cambridge, Cambridge University Press). https://doi.org/10.1017/CBO9780511803123

Gobierno de la República (2013), 'Estrategia Nacional de Cambio Climático: Visión 10-20-40', (Secretaría de Medio Ambiente y Recursos Naturales); English version 'The National Climate Change Strategy: 10-20-40 Vision'.

https://www.globalmethane.org/documents/The_National_Climate_Change_Strategy.pdf

Gough, C. \& Shackley, S. (2001), 'The Respectable Politics of Climate Change: The Epistemic

Communities and NGOs', International Affairs, 77: 329-46.

https://doi.org/10.1111/1468-2346.00195

Gouldson, A. (2009), 'Advances in Environmental Policy and Governance', Environmental Policy Governance, 19: 1-2. https://doi.org/10.1002/eet.497

Haris, S.M., Mustafa, F.B. \& Raja Ariffin, R.N. (2020), 'Systematic Literature Review of Climate Change Governance Activities of Environmental Nongovernmental Organizations in Southeast Asia', Environmental Management, 66: 816-25. https://doi.org/10.1007/s00267-020-01355-9

Haas, P.M. (1992), 'Introduction: Epistemic Communities and International Policy Coordination', International Organisation, 46(1): 1-35. https://doi.org/10.1017/S0020818300001442

Hsieh H.F. \& Shannon S.E. (2005), 'Three Approaches to Qualitative Content Analysis', Qualitative Health Research, 15 (9):1277-88. https://doi.org/10.1177/1049732305276687

Ibarrarán Viniegra, M.E., Boyd, R. \& Moreno Islas, L. (2011), 'Costly Commitments: Climate Change Policy in Mexico', Latin American Policy, 2(2): 222-33. https://doi.org/10.1111/j.2041-7373.2011.00040.x

IIED (International Institute for Environment and Development) (2019), 'Assessing Climate Adaptation in Mexico'. https://www.iied.org/assessing-climate-adaptation-mexico

INECC (Instituto Nacional de Ecología y Cambio Climático) (2019), México Ante el Cambio Climático. Acción Climática (Cd. De México, INECC).

IPCC (Intergovernmental Panel on Climate Change) (2007) Climate Change 2007: Synthesis Report. Contribution of Working Groups I, II and III to the Fourth Assessment Report of the Intergovernmental Panel on Climate Change Core Writing Team, R.K. Pachauri \& A. Reisinger (eds) (Geneva, IPCC). https://www.ipcc.ch/site/assets/uploads/2018/02/ar4_syr_full_report.pdf; https://doi.org/10.1017/CBO9781107415416

IPCC (Intergovernmental Panel on Climate Change) (2014), 'Summary for Policymakers', in O. Edenhofer et al. (eds) Climate Change 2014: Mitigation of Climate Change. Contribution of Working Group III to the Fifth Assessment Report of the Intergovernmental Panel on Climate Change (Cambridge, Cambridge University Press), 1-32.

Klein, J. \& Juhola. S. (2018), 'The Influence of Administrative Traditions and Governance on Private Involvement in Urban Climate Change Adaptation', Review of Policy Research, 35(6): 930-52. https://doi.org/10.1111/ropr.12294

Kooiman, J. (2003), Governing as Governance (London, SAGE).

Kuyper, J.W., Linnér, B.O. \& Schroeder, H. 2018, 'Non-state Actors in Hybrid Global Climate Governance: Justice, Legitimacy, and Effectiveness in a Post-Paris Era', Wires Climate Change, 9(1): e497. https://doi.org/10.1002/wcc.497 
Lane, M.B. \& Morrison, T.H. (2006), 'Public Interest or Private Agenda?: A Meditation on the Role of NGOs in Environmental Policy and Management in Australia', Journal of Rural Studies, 22(2): 232-42. https://doi.org/10.1016/j.jrurstud.2005.11.009

Lemos, M.C. \& Agrawal, A. (2006), 'Environmental Governance', Annual Review of Environment and Resources, 31(1): 297-325. https://doi.org/10.1146/annurev.energy.31.042605.135621

Mayring P. (2000), 'Qualitative Content Analysis', Forum Qualitative Social Research, 1(2): 20.

Murray, G. (2007), 'Constructing Paradise: The Impacts of Big Tourism in the Mexican Coastal Zone', Coastal Management, 35(2-3): 339-55. https://doi.org/10.1080/08920750601169600

Nature Conservancy (2018), 'Launch of the Coastal Zone Management Trust Quintana Roo, Mexico'. https://www.nature.org/content/dam/tnc/nature/en/documents/TNC_Mexico_ CoastalManagementTrust_Factsheet.pdf

Newell, P., Pattberg, P. \& Schroeder, H. (2012), 'Multiactor Governance and the Environment', Annual Review of Environment and Resources, 37: 365-87. https://doi.org/10.1146/annurev-environ-020911-094659

Newig, J. \& Fritsch, O. (2009), 'Environmental Governance: Participatory, Multi-level and Effective?' Environmental Policy and Governance, 19: 197-214. https://doi.org/10.1002/eet.509

Pedrozo-Acuña, A., Damania, R., Laverde-Barajas, M.A. \& Mira-Salama, D. (2015), 'Assessing the Consequences of Sea-level Rise in the Coastal Zone of Quintana Roo, México: The Costs of Inaction', Journal of Coastal Conservation, 19: 227-40. https://doi.org/10.1007/s11852-015-0383-y

Peters, B.G., \& Pierre, J. (1998), 'Governance Without Government? Rethinking Public Administration', Journal of Public Administration Research and Theory, 8(2): 223-43. https://doi.org/10.1093/oxfordjournals.jpart.a024379

Purcell, M. (2009), 'Hegemony and Difference in Political Movements: Articulating Networks of Equivalence', New Political Science, 31(3): 291-317. https://doi.org/10.1080/07393140903105959

Putnam, R.D. (2000), Bowling Alone: The Collapse and Revival of American Community (New York, Simon \& Schuster). https://doi.org/10.1145/358916.361990

Rantala, S., Hajjar, R. \& Skutsch, M. (2014), 'Multilevel Governance for Forests and Climate Change: Learning from Southern Mexico', Forests, 5: 3147-68. https://doi.org/10.3390/f5123147

Rootes, C., Zito, A. \& Barry, J. (2012), 'Climate Change, National Politics and Grassroots Action', Environmental Politics, 21(5): 677-90. https://doi.org/10.1080/09644016.2012.720098

Rubin, O. \& Rossing, T. (2012), 'National and Local Vulnerability to Climate-related Disasters in Latin America: The Role of Social Asset-based Adaptation', Bulletin of Latin American Research, 31(1): 19-35. https://doi.org/10.1111/j.1470-9856.2011.00607.x

Satterthwaite, D. \& Dodman, D. (2009), 'The Costs of Adapting Infrastructure to Climate Change', in M. Parry et al. (eds) Assessing the Costs of Adaptation to Climate Change. A Review of the UNFCCC and Other Recent Estimates (London, IIED and Grantham Institute for Climate Change, Imperial College London), 73-89.

Schreier M. (2012), Qualitative Content Analysis in Practice (London, SAGE).

Sosa-Núñez, G.S. (2015), 'Climate Change Policy and Energy Reform: An Assessment of Mexico's Foreign Policy', Latin American Policy, 6(2): 240-54. https://doi.org/10.1111/lamp.12077

Sosa-Rodriguez, F.S. (2014), 'From Federal to City Mitigation and Adaptation: Climate Change Policy in Mexico City', Mitigation and Adaptation Strategies for Global Change, 19: 969-96. https://doi.org/10.1007/s11027-013-9455-1

Thomas, K. et al. (2018), 'Explaining Differential Vulnerability to Climate Change: A Social Science Review', Wires, Climate Change, 10(2): e565. https://doi.org/10.1002/wcc.565

UNDP (United Nations Development Programme) (2020), 'Climate Change Adaptation: Mexico'. https://www.adaptation-undp.org/explore/mexico 
UN Environment (2017), 'State of Quintana Roo, Mexico'. http://www.cop-23.org/sponsors/quintanaroo\#: : :text=State $\% 20$ of $\% 20$ Quintana $\% 20$ Roo $\% 2 C \% 20$ Mexico $\% 20$ The $\% 20$ Planning $\% 20$ Committee,government $\% 20$ in $\% 20$ the $\% 20$ short $\% 2$ C $\% 20$ medium $\% 20$ and $\% 201$ ong $\% 20$ terms

United Nations (1992), United Nations Framework Convention for Climate Change. https://unfccc.int/ files/essential_background/background_publications_htmlpdf/application/pdf/conveng.pdf

von Lüpke, H. \& Well, M. (2020), 'Analyzing Climate and Energy Policy Integration: The Case of the Mexican Energy Transition', Climate Policy, 20(7): 832-45. https://doi.org/10.1080/14693062.2019.1648236

Vormedal, I. (2008), 'The Influence of Business and Industry NGOs in the Negotiation of the Kyoto Mechanisms: The Case of Carbon Capture and Storage in the CDM', Global Environmental Politics, 8: 36-65. https://doi.org/10.1162/glep.2008.8.4.36

\section{Notes on the authors}

Susan Baker, BA (Hons.), MA, PhD (EUI, Florence), PhD (h.c. Umea, Sweden), KSLA, FRSA, is Emerita Professor and Co-Director, Sustainable Places Research Institute, Cardiff University. Her research focuses on the governance of complex, social ecological systems.

Recent publications include:

Baker, S. \& Constant, N. (2020), 'Epistemic Justice and the Integration of Local Ecological Knowledge for Marine Conservation: Lessons from the Seychelles', Marine Policy, 117(July): 10392.1 https://doi.org/10.1016/j.marpol.2020.103921

Petursdottir, T., Baker, S. \& Aradottir, A.L. (2020), 'Functional Silos and Other Governance Challenges of Rangeland Management in Iceland', Environmental Science and Policy, 105(March): 37-46. https://doi.org/10.1016/j.envsci.2019.12.006

Baker, S. \& Chapin III, F. (2018), 'Going Beyond "It Depends:” The Role of Context in Shaping Participation in Natural resource Management', Ecology and Society, 23(1): 20. https://doi.org/10.5751/ES-09868-230120

https://orcid.org/0000-0002-5616-4157

Bárbara Ayala-Orozco is an Assistant Professor at the Institute for Ecosystem and Sustainability Research at the National Autonomous University of Mexico. She has undertaken research in natural resource management in protected areas, collaborative governance of natural resources, multi-stakeholder collaboration for sustainability, and participation in environmental management from a social-ecological perspective.

Recent publications include:

Baker, S., Ayala-Orozco, B. \& García-Frapolli, E. (2020), 'Hybrid, Public and Private Environmental Governance: The Case of Sustainable Coastal Zone Management in Quintana Roo, Mexico', International Journal of Sustainable Development and World Ecology, 27(7): 625-37. https://doi.org/10.1080/13504509.2020.1722764)

Ayala-Orozco, B. et al. (2018), 'Challenges and Strategies in Place-based Multi-stakeholder Collaboration for Sustainability: Learnings from Experiences in a Country of the Global South', Sustainability 10(9): 3217. https://doi.org/10.3390/su10093217

Merçon, J. et al. \& Ayala-Orozco, B. (2019), 'From Local Landscapes to International Policy: Contributions of the Biocultural Paradigm to Global Sustainability', Global Sustainability. https://doi.org/10.1017/sus.2019.4

https://orcid.org/0000-0002-9371-3151

Corresponding author: bayala@cieco.unam.mx 
Eduardo García-Frapolli is Professor at the Institute for Ecosystem and Sustainability Research at the National Autonomous University of Mexico. His research interests include social aspects of conservation, conservation conflicts and how local people, including indigenous communities, implement natural resources management strategies.

Latest publications included:

Cánovas-Molina, A. \& E. García-Frapolli, E. (2020), 'Untangling Worldwide Conflicts in Marine Protected Areas: Five Lessons from the Five Continents', Marine Policy, 121(November): 104185. https://doi.org/10.1016/j.marpol.2020.104185

Monroy-Sais S., E. García-Frapolli, E., et al. (2020), 'Unraveling Households' Natural Resource Management Strategies: A Case Study in Jalisco, Mexico', Ecosystem \& People, 16(1): 175-87. https://doi.org/10.1080/26395916.2020.1767213

Oliva, M., García-Frapolli, E. et al. (2019), 'Early Detection of Conflicts for the Management of Protected Areas: The Case of Charcoal Production in the Los Petenes Biosphere Reserve, Mexico', Environmental Management 64: 52-63. https://doi.org/10.1007/s00267-019-01170-x https://orcid.org/0000-0002-8278-750X

To cite the article: Susan Baker, Bárbara Ayala-Orozco and Eduardo García-Frapolli (2021), 'The role of civil society organisations in climate change governance: lessons from Quintana Roo, Mexico', Journal of the British Academy, 9(s10): 99-126. DOI https://doi.org/10.5871/jba/009s10.099

Journal of the British Academy (ISSN 2052-7217) is published by The British Academy, 10-11 Carlton House Terrace, London, SW1Y 5AH www.thebritishacademy.ac.uk 